\title{
CHRONIC HYPOPLASTIC ANAEMIA ARISING IN INFANCY
}

BY

\section{THOMAS ROBSON, M.D., M.R.C.P., and PATRICK J. SWEENEY, M.D., M.R.C.P., M.R.C.P.I.}

(From the Royal Victoria and West Hants Hospital)

An aplasia of the erythroblastic tissue in the bone marrow, without involvement of either leucocytes or platelets, is referred to by Whitby and Britton (1946) as a medical curiosity. This aplasia may be complete or partial. If complete, there is no formation of normal red-cell precursors. Strictly speaking, the term 'aplastic anaemia' should be reserved for cases of this kind, where there is a pure red-cell anaemia without involvement of leucocytes or platelets. If the aplasia is partial, then the term 'hypoplastic' is used. 'Aleukia haemorrhagica' (Frank, 1915) would be a better term to use for

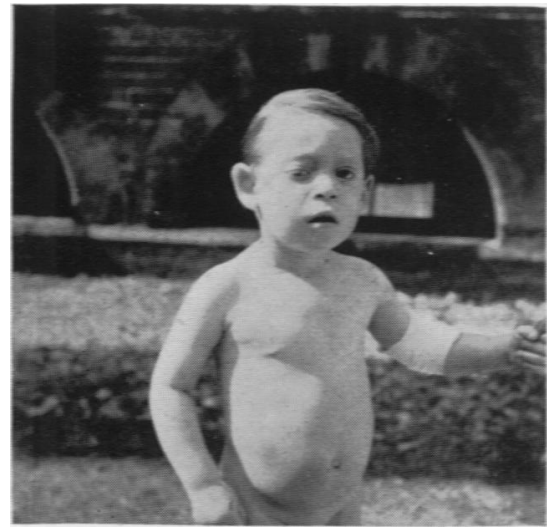

FiG. 1.- The patient.

conditions where red cells, leucocytes, and platelets are all reduced in numbers.

With the more general adoption of bone-marrow biopsy as a routine haematological investigation in cases of severe anaemia, a pure red-cell anaemia may be found to be more common than is thought at present. Such cases have been described in infants, children, and adults.

\section{Case Report}

D.S., aged $1 \frac{1}{2}$ years, an illegitimate male child, was admitted to the Royal Victoria and West Hants Hospital on Sept. 25, 1946, with a history of having been very pale since birth. The mother had no other children, he was born of a trial labour, and weighed $6 \mathrm{lb} .4 \mathrm{oz}$. at birth. He had been bottle-fed from birth (National Dried Milk), and there was no history of jaundice or other infection before admission.

Examination showed a very small pale child with a slight lemon tint to the skin and moderate ptosis of the right upper eyelid which had been present since birth (fig. 1). The central nervous system was otherwise normal. No abnoımality was detected in the cardiovascular or respiratory systems, and the liver and spleen were not palpable.

There was no koilonychia. He was afebrile,

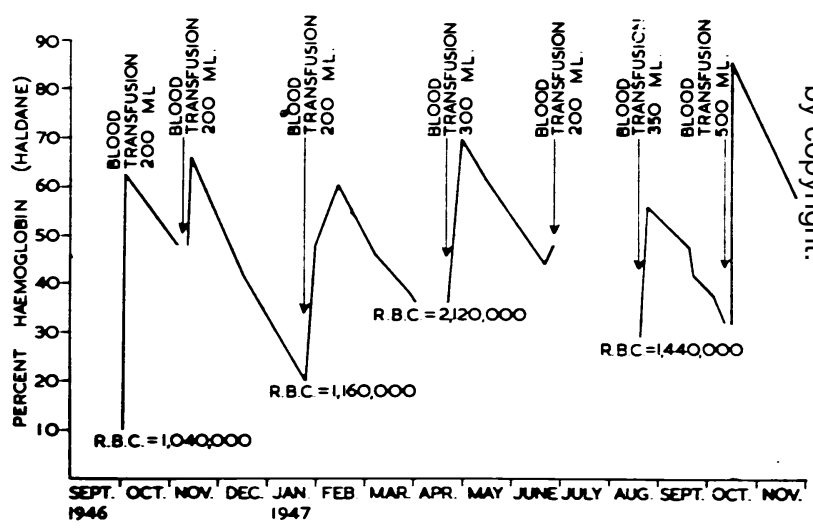

FIG. 2.-Showing per cent. haemoglobin. On Jan. 31, 1947, proteolysed liver, drachm 1 , three times a day, was begun, and there was an apparent response on Feb. 14, the $\mathrm{Hb}$. per cent. having risen from 48 to 60 . This good effect was not maintained, however, and on Apr. 1 the $\mathrm{Hb}$. per cent. was down to 36. The estimate of the $\mathrm{Hb}$. per cent. was unfortunately omitted after blood transfusion of June 27 , hence the gap in the chart.

weighing $17 \mathrm{lb}$. $5 \mathrm{oz}$, and was therefore approximately $5 \mathrm{lb}$. under weight for his age. Mentally he was backward, being unable to say words of more than one syllable. A blood count on admission showed severe anaemia (table 1) and a marrow puncture of two days later showed evidence of aplasia of the red-cell elements. A blood transfusion was given on Oct. 2 with good effect (fig. 2).

From that date onward blood transfusions 
TABLE 1

BLOOD EXAMINATIONS

\begin{tabular}{|c|c|c|c|c|c|c|c|c|c|c|}
\hline Date & R.B.C. & Hb. ${ }_{0}^{\circ}$ & C.I. & W.B.C. & P. & L. & M. & E. & Platelets & Retics. \\
\hline $\begin{array}{r}26.9 .46 \\
3.10 .46\end{array}$ & 1,230 & $\begin{array}{l}20 \\
62\end{array}$ & $0 \cdot 81$ & 12,200 & 23 & 72 & 3 & 2 & & \\
\hline $\begin{array}{r}16.10 .46 \\
6.11 .46 \\
14.11 .46 \\
19.12 .46 \\
8.1 .47\end{array}$ & & $\begin{array}{l}48 \\
66 \\
42 \\
30\end{array}$ & & & & & & . & & 0.05 \\
\hline $\begin{array}{l}24.1 .47 \\
31.1 .47\end{array}$ & 1,160 & $\begin{array}{l}20 \\
48\end{array}$ & $0 \cdot 86$ & 9,400 & 37 & 54 & 8 & 1 & & \\
\hline $\begin{array}{r}14.2 .47 \\
8.3 .47 \\
29.3 .47\end{array}$ & $\begin{array}{l}3,160 \\
2,720\end{array}$ & $\begin{array}{l}60 \\
46 \\
38\end{array}$ & $\begin{array}{l}0.95 \\
0.85\end{array}$ & $\begin{array}{r}7,200 \\
11,200\end{array}$ & $\begin{array}{l}29 \\
56\end{array}$ & $\begin{array}{l}64 \\
35\end{array}$ & $\begin{array}{l}2 \\
7\end{array}$ & $\begin{array}{l}5 \\
2\end{array}$ & & \\
\hline $\begin{array}{r}1.4 .47 \\
30.4 .47\end{array}$ & 2,120 & $\begin{array}{l}36 \\
70\end{array}$ & $0 \cdot 85$ & 8,600 & 39 & 55 & 5 & 1 & & \\
\hline $\begin{array}{l}15.5 .47 \\
21.6 .47 \\
26.6 .47\end{array}$ & $\begin{array}{l}3,520 \\
2,360\end{array}$ & $\begin{array}{l}62 \\
44 \\
48\end{array}$ & $\begin{array}{l}0.88 \\
0.93\end{array}$ & $\begin{array}{r}6,400 \\
12,600\end{array}$ & $\begin{array}{l}38 \\
39\end{array}$ & $\begin{array}{l}53 \\
56\end{array}$ & $\begin{array}{l}5 \\
5\end{array}$ & 4 & & \\
\hline $\begin{array}{r}7.8 .47 \\
24.8 .47\end{array}$ & $\begin{array}{l}1,440 \\
2,750\end{array}$ & $\begin{array}{l}29 \\
56\end{array}$ & 1.04 & 8,200 & 47 & 46 & 2 & 5 & 206,213 & None seen \\
\hline & $\begin{array}{l}2,640 \\
2,340\end{array}$ & $\begin{array}{l}48 \\
42\end{array}$ & $\begin{array}{l}0.92 \\
0.91\end{array}$ & $\begin{array}{r}10,800 \\
9,100\end{array}$ & 47 & 45 & 3 & 4 & 236,000 & None seen \\
\hline $\begin{array}{r}3.10 .47 \\
11.10 .47\end{array}$ & & 38 & & & & & & & & \\
\hline $\begin{array}{l}15.10 .47 \\
26.11 .47\end{array}$ & 3,310 & $\begin{array}{l}86 \\
58\end{array}$ & $0 \cdot 88$ & 16,800 & 40 & 52 & $5 \cdot 5$ & $2 \cdot 5$ & & \\
\hline
\end{tabular}

proved the only effective treatment. At different times he was given large doses of iron and crude liver preparations, yeast, ascorbic acid, and folic acid. Iron preparations containing traces of cobalt and manganese were tried. All forms of therapy excepting blood transfusion were without much effect.

Radiographs of the skull, chest, and long bones were normal. The Wassermann reaction was negative. Both mother and child are $\mathbf{R h}$-positive, and there was no Rh-antibody in the maternal serum. Urine examination was normal. Fat analysis of the stools was within normal limits. A fractional test meal in April, 1947, showed a complete achlorhydria, but when repeated after the subcutaneous injection of histamine it showed $18 \mathrm{ml}$. N/10 acid per cent. at the end of one hour. His weight in October, 1947, was $23 \frac{1}{2}$ lb. He was then still five or six pounds under weight, and his height, $31 \frac{1}{2}$ inches, was two or three inches below the average for his age. His mental condition had improved considerably.

Repeated blood counts during the year in which he was observed constantly showed a normocytic normochromic anaemia and very low or absent reticulocytes but normal platelets and leucocytes (table 1). The bleeding time, clotting time, and clot retraction were normal and no haemorrhagic manifestations occurred. The serum bilirubin was less than $0.2 \mathrm{mg}$. per $100 \mathrm{ml}$. of blood. Marrow puncture was performed six times in all. In September, 1947, a portion of marrow from the right tibia was removed under general anaesthesia and was examined by Dr. R. G. MacFarlane, who reported on the remarkable absence of red-cell precursors and who considered an erythroblastic hypoplasia, almost amounting to an aplasia, to be

TABLE 2

DETAILS OF TWO MYELOGRAMS

\begin{tabular}{lccc}
\hline \multicolumn{1}{c}{ Myelogram } & 1.10 .46 & 28.8 .47 \\
\cline { 2 - 3 } Premyelocytes & 3 & 2 \\
Myelocytes & 30 & 36 \\
Eosinophils & 7 & 1 \\
Polymorphs & 22 & 41 \\
Lymphocytes & 30 & 9 \\
Earty normoblasts & 1 & 1 \\
Late normoblasts & 7 & 10 \\
\hline
\end{tabular}

well established. Details of two myelograms are given in table 2 .

During the year the child was under observation he was remarkably free from intercurrent infections. When his haemoglobin was low he became drowsy and irritable and slight pyrexia was evident, but after a transfusion he became active and playful.

\section{Discussion}

The number of reported cases of aplasia or hypoplasia of the erythroblastic tissues alone is 
very few. Lescher and Hubble (1932), in an investigation on aplastic anaemia in general, could find only three recorded adult cases. Each of these cases survived only a short time after their diagnosis, the condition appearing to have been relatively acute. Mills, however, in 1931, recorded the case of a man aged 50 years in whom the disease ran an acute course, blood transfusion being ineffective and death occurring within four months. Bonemarrow biopsy was not performed. MacFarlane and Currie (1943) described the condition in a woman aged 22 years who died after a short illness, the immediate cause of death being fatal pyrexia following the second blood transfusion. The diagnosis in this case was confirmed by marrow biopsy, which showed aplasia of the red-cell elements. Kark (1937) described two very interesting cases, the first a man of $\mathbf{3 0}$ years who had two hundred and ninety blood transfusions in nine years, eventually dying from a transfusion reaction. At one period this patient developed severe agranulocytosis and eventually haemochromatosis, possibly due to a failure to excrete unutilized iron. Bone-marrow biopsy was reported as showing deficient haemopoietic tissue. Kark's second case was a girl aged 21, who had sixty-one transfusions during the three years she was under observation. She finally developed thrombocytopenia and died from uncontrollable bleeding. Leslie (1945) described the case of a child who developed an apparently pure red-cell anaemia six days after birth. This child recovered after two and a half months, following blood transfusions. Marrow biopsy was not performed.

Blackfan and Diamond (1944) described five cases which seem without doubt to be true examples of pure red-cell anaemia. Of their patients, all children, two eventually recovered completely following blood transfusions, one died of pneumococcal septicaemia, and two were still under treatment at the time of publication of the paper, the eldest, aged 11, fully developed and normal in every respect, but requiring regular transfusion.

Their description of chronic hypoplastic anaemia arising in infancy, and presumably congenital in origin, is identical with that of the case recorded here. In all their cases severe normocytic normochromic anaemia developed within the first three months of life. There was no familial incidence, and no history of infection either in the patient or in the mother during gestation. There was no evidence of endocrine disturbance and little interference with growth and development; and with the exception of the one who died from pneumococcal septicaemia the children were remarkably free from infection. Blackfan and Diamond's statement that after many years' transfusions pigmentation suggestive of mild haemochromatosis develops, corresponds with Kark's experience as mentioned above.

Though in their cases the liver and spleen were not at first palpable, after some years these organs began to enlarge. The marrow showed aplasia of the red-cell elements only. Leucocytes and platelets were always normal. The bleeding times, clotting times, and clot retractions were normal. The only treatment they found effective was blood transfusion at regular intervals of six to eight weeks.

The case here recorded closely fits the above description, and is of added interest in view of the associated congenital ptosis. The ultimate outcome is uncertain, though in view of Blackfan and Diamond's report of recovery following repeated transfusions in two of their cases it appears justified to continue transfusions in the case described.

\section{Summary}

1. A case of chronic hypoplastic anaemia arising in early infancy is described.

2. From a survey of the literature it would appear that this disease can occur in infants, children, and adults, and may be acute or chronic, presumably depending upon the degree of aplasia of the red-cell elements in the bone marrow.

3. The cases arising in early infancy are probably congenital in origin, but as stated by Wintrobe (1946), there is no information about the cause of this disorder.

Our thanks are due to Dr. Facey for the numerous blood investigations, and to Dr. R. G. MacFarlane (Radcliffe Infirmary, Oxford), who examined the bone-marrow sections.

\section{REFERENCES}

Blackfan, K. D., and Diamond, L. K. (1944). Atlas of the Blood in Children. New York.

Frank, E. (1915). Berl. Klin. Wschr., 52, 961.

Kark, R. M. (1937). Guys Hosp. Rep., 87, 343.

Lescher, F. G., and Hubble, D. (1932). Quart. J. Med., $1,425$.

Leslie, J. T. (1945). J. Pediat., 27, 265.

MacFarlane, J. W., and Currie, J. P. (1943). Edinb. med. J., $50,171$.

Mills, E. S. (1931). Amer. J. med. Sci., 181, 521.

Whitby, L. E. H., and Britton, C. J. C. (1946). Diseases of the Blood. London.

Wintrobe, M. M. (1946). Clinical Hematology. London. 